\title{
PENGEMBANGAN PANDUAN PERMAINAN UNTUK ENGOPTIMALKAN PERKEMBANGAN SOSIAL EMOSIONAL ANAK USIA DINI
}

\author{
Oleh: \\ Muthmainnah, Budi Astuti, Arumi Savitri Fatiamaningrum \\ FIP Universitas Negeri Yogyakarta \\ Diwan_nafil@yahoo.co.id; budi_astuti@uny.ac.id; arumi.fatimaningrum@yahoo.com
}

\begin{abstract}
Abstrak
Penelitian ini bertujuan untuk mengembangkan panduan permainan guna mengoptimalkan perkembangan sosial emosional anak usia dini. Penelitian ini mengacu pada model pengembangan Borg \& Gall namun hanya sampai pada tahap 3 yaitu pengembangan produk awal sesuai penilaian dan saran validator. Teknik pengumpulan data menggunakan skala dengan instrumen lembar skala.Analisis data menggunakan analisis kuantitatif. Data kuantitatif kemudian dikonversikan ke data kualitatif dengan rumus persentase untuk mengetahui kualitas produk. Target penelitian ini adalah terciptanya ragam permainan dan panduan penggunaannya yang dapat digunakan sebagai alternatif metode pembelajaran di PAUD yang dapat mengembangkan kemampuan sosial emosional anak. Berdasarkan penilaian dari kedua validator, maka panduan yang telah dibuat peneliti dinyatakan layak diuji coba lapangan dengan revisi. Secara keseluruhan, apabila data kuantitatif dikonversikan ke data kualitatif diperoleh hasil untuk uji materi $84,37 \%$ (baik) dan hasil untuk uji media $87,5 \%$ (sangat baik).
\end{abstract}

Kata kunci: pengembangan, panduan permainan, sosial emosional, anak

This research is aimed at developing the game user guide to optimize the development of social emotional of the early children. This research refers to the basic developing models of Borg and Gall but only up to the stage number 3 is the development of a prototype or first draft with the assessment of the validator. The technique of collecting data using a scale with scale sheet instruments and data analysis using quantitative data analysisThe quantitative data is then converted in to the qualitaitive data with percentage formula to find the product quality. The target of this research is the development of variety in games and user guide that can be used as one alternative method of learning activity in PAUD which in turn can nurture children'a socia emotional skills. Based on the assesment validator, the modified Snake and Ladder and the user guide book made by the researchers is stated as eligible for the field testing with some revisions. This can be seen from the instrument testing by the validator experts, which over all the result of material testing is $84,37 \%$ (good) and the result of media testing is $87,5 \%$ (excellent).

Keywords: developing, game user guide, social emotional, children

\section{PENDAHULUAN}

Perkembangan sosial emosional dapat dioptimalkan dengan berbagai cara, salah satunya melalui permainan. Permainan merupakan salah satu metode yang dapat dilakukan untuk mengoptimalkan perkembangan sosial emosional seperti kerjasama, interaksi, tanggung jawab, kejujuran, sportivitas, kejujuran, sportivitas, dan sebagainya. Masa usia dini merupakan masa bermain yang mana sebagian waktunya digunakan 
untuk bermain. Hal ini diperkuat oleh pendapat Diana Mutiah (2010: 91) yang menyatakan bahwa pada dasarnya anakanak belajar melalui permainan. Melalui bermain, anak usia dini tumbuh dan mengembangkan seluruh aspek perkembangan yang ada pada dirinya baik fisik, intelektual, bahasa dan perilakunya. Bermain juga dapat berfungsi sebagai terapi dalam kehidupan anak karena dengan bermain anak mengekspresikan hal-hal yang berhubungan dengan ranah afektif, perasaan, emosi, pikiran maupun konatif (Agoes Dariyo, 2007: 231). Sigmund Freud juga menyatakan bahwa bermain merupakan sarana katarsis untuk mengatasi masalah psikoemosional individu (Agoes Dariyo, 2007: 231). Hal senada disampaikan oleh Yudrik Jahja (2011: 192) bahwa permainan dapat mengasah fungsi emosi anak karena melalui permainan memungkinkan anak belajar menyelesaikan sebagian masalahnya, belajar mengatasi kegelisahan dan konflik batin. Permainan juga membantu anak membebaskan perasaan yang terpendam karena tekanan batin terlepas melalui permainan.Melalui permainan, diharapkan dapat meningkatkan minat dan antusias anak dalam mengikuti kegiatan pembelajaran.

Dalam pembelajaran di TK, sebagian guru masih jarang menerapkan permainan, baik permainan tradisional maupun modern, baik outdoor maupun indoor. Berdasarkan hasil observasi di lima TK di daerah Bantul diperoleh data empat TK pernah menerapkan metode permainan, misalnya dengan permainan kucing tikus, menjala ikan dan lempar tangkap bola, namun pelaksanaannya pun tidak rutin, hanya bersifat insidental. Pada umumnya kegiatan di TK lebih didominasi dengan kegiatan individu seperti mengerjakan Lembar Kegiatan Anak (LKA) di dalam kelas. Anak juga lebih banyak duduk dan memegang pensil atau krayon dalam pembelajaran. Apabila pembelajaran tidak sama sekali atau minim menggunakan model kelompok, dikhawatirkan perkembangan sosial seperti kerjasama dan perkembangan emosi seperti pengendalian diri kurang terasah dengan baik.

Hasil wawancara dengan empat guru TK menunjukkan bahwa jarangnya dilakukan permainan disebabkan oleh kurangnya lahan untuk bermain dan keterbatasan pengetahuan guru TK untuk mengembangkan permainan. Permainan yang dilakukan hanyalah permainan umum seperti ular naga, kucing dan tikus, gobag sodor dan beberapa permainan umum lainnya yang belum dikembangkan oleh guru. Pembelajaran melalui permainan yang beragam, baik outdoor maupun indoor diharapkan dapat meningkatkan minat dan antusias anak dalam mengikuti pembelajaran sekaligus meningkatkan aspek perkembangan anak. Anak dapat belajar banyak hal melalui permainan. Diharapkan pula, keterbatasan lahan tidak menjadi kendala atau hambatan bagi guru untuk menyelenggarakan pembelajaran kelompok. Oleh karena itu, berdasarkan adanya permasalahan tentang keterbatasan pengetahuan guru tentang ragam permainan untuk mengasah perkembangan sosial emosional, mendorong peneliti untuk mengembangkan panduan model permainan sesuai tema yang dapat dikembangkan di TK untuk membantu memberikan gambaran tentang beberapa permainan yang dapat diimplementasikan di TK dalam rangka mengoptimalkan perkembangan sosial emosional anak.

\section{Rumusan Masalah}

Rumusan masalah dalam penelitian ini adalah: "bagaimana panduan permainan untuk mengoptimalkan perkembangan sosial emosional anak?”.

\section{Tujuan Penelitian}

Penelitian ini memiliki menghasilkan produk berupa panduan permainan untuk mengoptimalkan perkembangan sosial emosional anak usia dini. 


\section{Manfaat Penelitian}

Hasil penelitian ini diharapkan bermanfaat bagi pengembangan model pembelajaran, baik secara teoritis maupun praktis.

1. Manfaat Teoritis

a. Hasil penelitian ini dapat memberikan kejelasan teoretis tentang ragam permainan untuk pengembangan sosial emosional anak.

b. Hasil penelitian ini dapat memberikan wawasan berpikir ilmiah kepada berbagai pihak yang berkompeten.

2. Manfaat Praktis

Hasil penelitian ini diharapkan bermanfaat bagi:

a. Dosen dan guru: untuk menambah khazanah pengetahuan tentang model permainan untuk pengembangan sosial emosional anak.

b. Peneliti selanjutnya: peneliti dapat melakukan penelitian lanjutan atau lainnya terkait dengan penerapan permainan dan keefektifannya untuk pengembangan sosial emosional anak.

\section{Bermain dan Permainan}

Bermain merupakan kegiatan yang dapat memberikan informasi, memperluas pengetahuan, memberi kesenangan maupun mengembangkan daya imajinasi pada anak. Hal ini sesuai dengam pendapat Dockett dan Fleer (2000: 41-43) yang menyatakan bahwa bermain merupakan kebutuhan karena melalui bermain anak akan memperoleh pengetahuan yang dapat mengembangkan kemampuan dirinya. Bagi anak, bermain tidak hanya sekedar mengisi waktu, tapi sebagai sarana anak untuk belajar atau lebih dikenal dengan "bermain sambil belajar". Bermain dapat dilakukan dengan atau tanpa menggunakan alat. Anggani Sudono (2000) juga mengungkapkan bahwa bermain adalah suatu kegiatan yang dilakukan dengan atau tanpa mempergunakan alat yang menghasilkan pengertian atau memberikan informasi, memberi kesenangan maupun mengembangkan imajinasi pada anak. Mayke S. Tedjasaputra (1995) juga menyatakan bahwa bermain merupakan pengalaman belajar yang sangat berguna untuk anak, misalnya saja memperoleh pengalaman dalam membina hubungan dengan sesama teman, menambah perbendaharaan kata, menyalurkan perasaan-perasaan tertekan dan sebagainya.

Permainan merupakan sebuah aktivitas rekreasi dengan tujuan bersenang-senang, mengisi waktu luang, atau berolahraga ringan. Permainan biasanya dilakukan sendiri atau bersamasama (kelompok) (http://id.wikipedia.org/wiki/permainan).

Permainan merupakan kegiatan yang menggunakan alat bermain seperti balok, puzzle atau benda-benda lain yang dianggap bisa dimainkan. Banyak cara untuk bermain dan ragamnya permainan yang dapat dimainkan anak, misalnya bermain pura-pura, bermain bebas dan spontan, bermain dramatic, dan bermain sendiri.

\section{Teori Bermain}

Secara umum teori-teori tentang bermain dapat digolongkan menjadi dua, yaitu: Teori Klasik dan Modern (Agoes Dariyo, 2007: 225-229).

a. Teori Klasik

1) Teori Kelebihan Energi dikemukakan oleh Herbert Spencer dan Freidrich Schiler yang menyatakan bahwa bermain merupakan kegiatan yang menyenangkan yang berfungsi untk menyalurkan kelebihan energi yang dimiliki oleh anak agar mencapai keseimabnagan energi dalam tubuhnya.

2) Teori Rekreasi dikemukakan oleh Moritz Lazarus yang menjelaskan bahwa bermain dapat mengisi kembali energi yang telah terpakai dalam bekerja.

Teori Praktis dikemukakan oleh Karl 
Groos yang menyatakan bahwa bermain memiliki tujuan untuk mereduksi atau mengurangi insting mau agar dapat melakukan aktivitas di masa mendatang.

3) Teori Rekapitulasi dikemukakan oleh Stanley Hall yang menyatakan bahwa bermain sebagai upaya untuk mengurangi insting kuno yang umumnya dilakukan oleh spesies binatang

\section{b. Teori Modern}

Teori Modern menyatakan bahwa bermain memiliki manfaat untuk mengatasi kecemasan, mengembangkan kemampuan intelektual atau mempertahankan kemampuan berpikir stabil dan luwes dalam menghadapi permasalahan hidup.

1) Teori Psikoanalisa dikemukakan Sigmund Freud yang memandang bermain sebagai katarsis yaitu bermain dapat mengurangi ketegangan emosi yang dialami anak karena anak merasa senang.

2) Teori Perkembangan Kognitif dikemukakan Jean Piaget yang menyatakan bahwa bermain merupakan kegiatan yang menyenangkan untuk mengembangkan kemampuan intelektual anak, seperti memecahkan masalah (problem solving), berpikir kreatif (creative thinking), menggunakan strategi kognitif (cognitive strategy), serta memperoleh cara atau ide baru untuk menjalani kehidupannya.

3) Teori Kontekstual dikemukakan Lev Vygotsky yang menekankan pada lingkungan sosial budaya yang menjadi sumber bagi anak seperrti perkembangan bahasa dan berpikir.

4) Teori Modulasi dikemuakan Michael Ellis dan Fein yang memandang bermain dapat membantu anak mengurangi kejenuhan dan perasaan yang tidak menyenangkan pada diri anak.

\section{Fungsi dan Manfaat Bermain}

Kegiatan bermain memiliki pengaruh yang sangat besar terhadap perkembangan seorang anak. Hal ini sebagaimana yang dijelaskan oleh Hurlock (1978) bahwa terdapat pengaruh bermain bagi perkembangan anak yaitu: perkembangan fisik, dorongan berkomunikasi, penyaluran bagi energi emosional yang terpendam, penyaluran bagi kebutuhan dan keinginan, sumber belajar, rangsangan kreativitas, perkembangan wawasan diri, belajar bermasyarakat, standar moral, belajar bermain sesuai dengan peran jenis kelamin serta perkembangan ciri kepribadian yang diinginkan. Eheart dan Leavitt (Yuliani Nurani, 2010: 36) berpendapat bahwa kegiatan bermain dapat mengembangkan berbagai potensi pada anak, tidak saja pada potensi fisik tetapi pada perkembangan kognitif, bahasa, sosial, emosi, kreativitas dan pada akhirnya prestasi akademik.

\section{Tahapan Perkembangan Bermain}

Parten (Santrock, 2009: 217) mengelompokkan tahapan-tahapan bermain anak yaitu:

a. Unoccupied Play

Pada tahapan ini, anak hanya mengamati kejadian di sekitarnya. Apabila tidak ada hal yang menarik, maka anak akan menyibukkan dirinya sendiri.

b. Solitary Play

Pada tahapan ini, anak bermain sendiri dan tidak berhubungan dengan permainan teman-temannya. Anak menikmati kegiatannya sendiri, belum memiliki minat terhadap lingkungan sekitar.

\section{c. Onlooker Play}

Pada tahapan ini, anak melihat atau memperhatikan anak lain yang sedang bermain. Anak-anak mulai memperhatikan lingkungannya dan mulai mengembangkan kemampuannya untuk memahami bahwa dirinya adalah bagian dari lingkungan, namun anak belum memutuskan untuk bergabung. 


\section{d. Parallel Play}

Pada tahapan ini, anak bermain dengan temannya bahkan sudah bergabung dengan kelompok. Anak mulai tertarik satu sama lain, namun belum ada satu tujuan yang ingin dicapai bersama.

e. Associative Play

Pada tahapan ini, anak sudah mulai melakukan interaksi, kerjasama dan kesamaan tujuan yang ingin dicapai bersam.

\section{f. Cooperative Play}

Pada tahapan ini, anak sudah mampu bekerjasama atau membagi tugas/peran untuk mencapai satu tujuan tertentu.

Menurut Hurlock (Mursalin, 2011), tahapan bermain terdiri dari empat tahapan yaitu:

a. Tahap Penjelajahan (Exploartory stage)

Pada tahap ini berupa kegiatan mengenai obyek atau orang lain, mencoba menjangkau atau meraih benda disekelilingnya lalu mengamatinya.

\section{b. Tahap Mainan (Toy Stage)}

Tahap ini mencapai puncaknya pada usia 5-6 tahun. Antara usia 2-3 tahun anak biasanya hanya mengamati alat permainannya. Mereka pikir benda mainannya dapat makan, berbicara, merasa sakit dan sebagainya. Contohnya yaitu bermain dengan boneka dan mengajaknya bercakap atau bermain seperti layaknya teman bermainnya.

c. Tahap Bermain (Play Stage)

Pada tahap ini, terjadi bersamaan dengan mulai masuknya anak ke Sekolah Dasar. Pada masa ini jenis permainan anak semakin bertambah banyak, karena itu tahap ini dinamakan tahap bermain. Anak bermain dengan alat permainan yang lama kelamaan berkembang menjadi games, olah raga, dan bentuk permainan lain yang dilakukan juga oleh orang dewasa.

d. Tahap Melamun (Daydream Stage)

Tahap ini diawali saat anak mendekati masa puber. Saat ini anak sudah mulai kurang berminat terhadap kegiatan bermain yang tadinya mereka sukai dan mulai banyak menghabiskan waktunya untuk melamun atau berkhayal. Biasanya lamunan atau khayalannya mengenai perlakuan kurang adil dari orang lain.

\section{Ragam Permainan}

Menurut Diana Mutiah (2010: 161), ragam permainan anak terdiri dari permainan dengan angka, bermain melalui gerak dan lagu serta permainan kreatif. Apabila ditinjau dari pelaksanaannya, kegiatan bermain terdiri dari bermain bebas dan bermain terpimpin. Bermain bebas merupakan kegiatan yang mana anak-anak boleh memilih kegiatan dan alat bermain yang disukai, sedangkan kegiatan bermain terpimpin merupakan kegiatan bermain yang telah dipersiapkan guru dan disesuaikan dengan tema. Aktivitas dalam kegiatan bermain terpimpin seperti permainan dalam lingkaran, permainan dengan alat, permainan tanpa alat, permainan dengan nyanyian, permainan dalam bentuk lomba, permainan dengan angka, dan permainan mengasah panca indera (BEF Montolalu: 2009).

\section{Perkembangan Sosial}

Perkembangan sosial adalah perolehan kemampuan berperilaku yang sesuai dengan tuntutan dan harapan sosial. Perkembangan sosial dapat dimaknai pula sebagai kemampuan anak untuk berinteraksi dengan lingkungannya, bagaimana anak tersebut memahami keadaan lingkungan dan mempengaruhinya dalam berperilaku, baik kepada dirinya sendiri maupun kepada orang lain (Hurlock, 1978: 250). Dalam perkembangan sosial terjadi proses belajar untuk menyesuaikan diri terhadap normanorma kelompok, moral, tradisi dan meleburkan diri menjadi satu kesatuan, saling berkomunikasi dan kerjasama. Perkembangan sosial mencerminkan pencapaian kematangan dalam hubungan sosial.

Upaya menjadi orang yang mampu bermasyarakat (sozialized) memerlukan tiga proses. Masing-masing proses 
terpisah, tetapi saling berkaitan. Ketiga proses tersebut adalah belajar berperilaku yang dapat diterima sosial, memainkan peran sosial yang dapat diterima, dan perkembangan sikap sosial untuk bersedia menggabungkan diri dan menyesuaikan diri dalam kegiatan bersama (Hurlock, 1978: 250). Melalui ketiga proses tersebut, anak belajar bagaimana berinteraksi dalam kehidupan sosial, mulai mengenal perbedaaan, dan menyesuaikan diri dengan aturan kelompok agar dapat diterima secara sosial.

Perkembangan sosial anak-anak dapat dilihat dari tingkatan kemampuannya dalam berhubungan dengan orang lain dan menjadi anggota masyarakat sosial yang produktif. Perkembangan sosial meliputi kompetensi sosial (kemampuan untuk bermanfaat bagi lingkungan sosialnya), kemampuan sosial (perilaku yang digunakan dalam situasi sosial), pengamatan sosial (memahami pikiran-pikiran, niat, dan perilaku diri sendiri maupun orang lain), perilaku prososial (sikap berbagi, menolong, bekerjasama, empati, menghibur, meyakinkan, bertahan, dan menguatkan orang lain) dan perolehan nilai dan moral (perkembangan standar untuk memutuskan mana yang benar atau salah, kemampuan untuk memperhatikan keutuhan dan kesejahteraan orang lain).

Perkembangan sosial anak dipengaruhi oleh proses perlakuan dan bimbingan terhadap anak dalam mengenal berbagai aspek kehidupan sosial serta mendorong dan memberikan contoh kepada anak (Syamsu Yusuf LN: 2004, 122). Anak juga dapat belajar mengadakan hubungan emsosional dengan orangtua, saudara dan orang tua (Syamsu Yusuf LN: 2004, 68).

\section{Faktor-faktor yang Mempengaruhi Perkembangan Sosial}

Hurlock (1978) mengunghkapkan bahwa faktor-faktor yang mempengaruhi perkembangan sosial, yaitu:

a. Keluarga
Selama masa prasekolah, keluarga merupakan agen sosialisasi yang terpenting. Keluarga merupakan lingkungan pertama yang memberikan pengaruh terhadap berbagai aspek perkembangan anak, termasuk perkembangan sosialnya. Keluarga juga merupakan tempat anak-anak mendapatkan nilai-nilai dalam masa awal perkembangannya. Anggota keluarga terutama orangtua merupakan model bagi anak-anak dalam berperilaku. Oleh karena itu, orang tua hendaknya dapat menerapkan pola asuh yang tepat dan bijak, sehingga membantu anak mencapai tugas perkembangannya.

b. Kematangan

Untuk dapat bersosialisasi dengan baik diperlukan kematangan fisik dan psikis, sehingga mampu mempertimbangkan proses sosial. Menerima masukan orang lain memerlukan kematangan intelektual dan emosional.

c. Pengaruh teman sebaya

Menurut Havighurst (Hurlock, 1978), teman sebaya adalah kumpulan orang-orang yang kurang lebih berusia sama danbertindak bersama-sama. Anakanak mulai membentuk hubungan dengan teman sebaya pada masa kanak-kanak akhir. Teman sebaya menjadi orang-orang yang penting dalam sosialisasi anakkarena interaksi antar teman sebaya membuat anak mengerti mengenai hubungan sosial yang lebih besar daripada hanya sekedar keluarga. Pendapat dari teman sebaya biasanya menjadi hal yang sangat diperhatikan dan didengarkan oleh anakanak seusianya apalagi seorang anak yang merupakan "star" atau pemimpin kelompok tersebut. Anak-anak berusaha untuk bertindak sesuai dengan yang diharapkan kelompoknya agar dapat diterima oleh kelompok. Melalui pengaruh teman sebaya ini, anak-anak dapat belajar menyesuaikan diri dengan tuntutan sosial, membantu anak-anak mencapai kemandirian, dan membentuk konsep diri anak. 


\section{d. Sekolah}

Sekolah menjadi hal yang mempengaruhi perkembangan sosialisasi anak karena salah satu fungsi sekolah untuk anak usia dini adalah mengembangkan kemampuan sosialisasi agar anak dapat menyesuaikan diri dengan lingkungannya.

e. Status Sosial Ekonomi

Kehidupan sosial banyak dipengaruhi oleh kondisi sosial ekonomi keluarga dalam masyarakat. Perilaku anak akan banyak memperhatikan kondisi normatif yang telah ditanamkan oleh keluarganya.

Senada dengan pendapat Yudrik Jahja (2011: 445) bahwa perkembangan sosial anak dipengaruhi oleh tiga faktor yaitu keluarga, masyarakat, dan sekolah. Perkembangan sosial anak ditandai dengan meluasnya lingkungan pergaulan. Meluasnya lingkungan sosial meneyebabkan anak mendapat pengaruh dari luar lingkungan keluarga seprti teman sebaya.

\section{Perkembangan Emosi}

Perkembangan emosi adalah perkembangan yang mengarah pada kegiatan mengenal, mengekspresikan dan memberikan reaksi emosional. Emosi merupakan perasaan yang menyimpang dari batas normal,sehingga yang mengalami kadang-kadang menguasai diri dan terganggu penguasaannya dengan lingkungan. Pengembangan emosi anak dapat diarahkan sesuai lingkup perkembangan anak. Salah satunya mengacu pada tingkat pencapaian perkembangan anak yang ada dalam kurikulum PAUD yaitu: menunjukkan sikap mandiri, mengendalikan perasaan, menunjukkan rasa percaya diri, menunjukkan sikap toleran, mengekspresikan emosi sesuai dengan keadaan, menunjukkan rasa empati yaitu memahami perasaan dan masalah orang lain, berpikir dari sudut pandang orang lain, dan mampu menghargai perbedaan orang lain, memiliki sikap gigih (tidak mudah menyerah) dan bangga terhadap hasil karya sendiri.

Pengembangan sosial anak juga diarahkan sesuai lingkup perkembangan anak. Salah satunya juga mengacu pada tingkat pencapaian perkembangan anak yang ada dalam kurikulum PAUD yaitu: mau berbagi, menolong, dan membantu teman; menunjukkan antusiasme dalam melakukan permainan kompetitif secara positif; menaati aturan yang berlaku dalam suatu permainan; menjaga diri sendiri dari lingkungannya; dan menghargai orang lain. Pengembangan sosial diharapkan dapat mengarahkan anak dari sifat egosentris ke arah sosiosentris, memperluas pertemanan anak, dan membantu anak belajar menyesuaikan diri agar dapat diterima secara sosial.

\section{METODE PENELITIAN}

Model Pengembangan

Panduan model permainan untuk pengembangan sosial emosional anak dikembangkan berdasarkan model pengembangan produk Borg \& Gall (1983) yang meliputi sepuluh langkah kegiatan pengembangan,namun dalam penelitian ini hanya sampai pada tahapan nomor lima, yaitu melakukan revisi terhadap produk utama sesuai saran ahli media dan ahli materi panduan permainan serta hasil wawancara dan observasi terhadap guru dalam uji lapangan awal.

\section{Lokasi Penelitian}

Lokasi penelitian ini di TK Masyithoh Dukuh Imogiri Bantul Yogyakarta.

\section{Prosedur Pengembangan}

Pengembangan penelitian ini mengacu pada model dasar pengembangan Borg \& Gall (1983) yang hanya sampai pada tahapan nomor 3, yaitu pengembangan produk awal atau prototipe dan melakukan revisi terhadap produk awal sesuai saran validator. Validator media dan materi dilakukan oleh expert judgement dari dosen PAUD FIP UNY. 


\section{Instrumen Pengumpulan Data}

Dalam penelitian ini instrumen pengumpul data kuantitatif yang digunakan berupa: skala uji media dan uji materi yang disertai saran dan masukan tertulis.

\section{Teknik Analisis Data}

Teknik analisis data yang digunakan dalam penilaian akseptabilitas panduan yaitu analisis data kuantitatif. Data uji ahli berdasarkan skala penilaian dianalisis secara kuantitatif dengan menggunakan penskoran. Data kuantitatif diperoleh melalui penskoran instrumen panduan permainan oleh ahli. Data kuantitatif tersebut kemudian dikonversikan ke data kualitatif dengan rumus persentase untuk mengetahui kualitas produk. Konversi yang dilakukan terhadap data mengacu pada pendapat Suharsimi Arikunto (2006) sebagai berikut:

Kriteria Penilaian Panduan Permainan

\begin{tabular}{|l|l|l|}
\hline No. & Kriteria & Persentase \\
\hline 1. & Sangat Baik & $86 \%-100 \%$ \\
\hline 2. & Baik & $71 \%-85 \%$ \\
\hline 3. & Cukup & $56 \%-70 \%$ \\
\hline 4. & Tidak Baik & $<40 \%$ \\
\hline
\end{tabular}

\section{HASIL PENELITIAN DAN \\ PEMBAHASAN \\ Hasil Penelitian}

Penelitian ini terdiri dari berbagai rangkaian kegiatan diantaranya yaitu melakukan studi literatur dan identifikasi kebutuhan untuk pengembangan panduan permainan dalam mengoptimalkan perkembangan sosial emosional anak. Kegiatan ini dilakukan dengan cara literatur eksploratorik dan wawancara dengan empat guru di TK Masyithoh Dukuh Imogiri Bantul. Literatur eksploratorik dilakukan dengan cara mengkaji berbagai teori permainan dan metode pembelajaran anak TK. Wawancara dilakukan dengan guru dan kepala sekolah TK Masyithoh Dukuh Imogiri Bantul untuk mengetahui penggunaan permainan dalam pembelajaran yang selama ini sudah digunakan di TK. Berdasarkan hasil wawancara diperolehinformasi bahwa permainan sudah digunakan, namun terbatas pada pengembangan fisik motorik kasar.

Penelitian merancang panduan permainan sebagai salah satu acuan guru dalam mengembangkan metode pembelajaran untuk meningkatkan kemampuan sosial emosional anak. Panduan permainan ini berisi 60 permainan anak yang dilengkapi dengan nama permainan, tujuan permainan, alat dan bahan yang digunakan, langkahlangkah, refleksi permainan, serta variasi permainan. Panduan ini juga disertai dengan ilustrasi gambar agar memberikan kemudahan pengguna panduan dalam memahami penerapan atau praktek permainan. Permainan-permainan ini dapat dilakukan di dalam kelas (indoor) maupun di luar kelas (outdoor), dengan alat dan bahan sederhana yang dapat divariasi dengan media yang ada di TK agar tidak merepotkan, dan disertai dengan refleksi agar anak-anak memahami nilai-nilai yang diperoleh melalui permainan.

Panduan permainan yang berisi 60 permainan selanjutnya diuji oleh dua validator, yaitu ahli media dan ahli materi yang keduanya merupakan dosen Pendidikan Anak Usia Dini. Berdasarkan penilaian dari kedua validator, maka buku panduan yang telah dibuat peneliti dinyatakan layak diuji coba lapangan dengan revisi. Hal ini dapat dilihat dari pengujian instrumen oleh validator dari ahli materi yang menunjukkan bahwa dari 8 indikator panduan menunjukkan 5 indikator $(62,5 \%)$ dinyatakan baik, dan 3 indikator $(37,5 \%)$ dinyatakan sangat baik. Pengujian instrumen oleh validator dari ahli media menunjukkan bahwa dari 6 indikator panduan menunjukkan 3 indikator $(50 \%)$ dinyatakan baik, dan 3 indikator $(50 \%)$ dinyatakan sangat baik. Secara keseluruhan, apabila data kuantitatif dikonversikan ke data kualitatif diperoleh hasil untuk uji materi 84,37\% 
(Baik) dan hasil untuk uji media 87,5\% (Sangat Baik).

Secara keseluruhan 60 permainan terdiri dari Tepuk Perkenalan, Bola Perkenalan, Tepuk Hobi, Tepuk Cita-cita, Lempar Kantong Biji, Jalan Kepiting, Lompat Katak, Lompati Simpai, Bola Beranting, Lari Zig-zag Bergantian, $\mathrm{C}-\mathrm{O}$ $C-O-N-U-T$, Gobag Bundar Simpang Tiga, Marina Menari di Atas Menara, "Balonku Ada Lima", guru berkata....., Melipat Baju, Pakai Baju Sendiri, Tunjukkan Waktunya, Ayo...Tampilkan, Buah Kesukaanku, Sapu Tangan Bergilir, Berbaris sesuai Urutan Angka, Urutkan dengan Garis, Ayo......Mengurutkan,

Ayo.....Mengelompokkan, Keluarga Burung, Burung Terbang, Gajah, Jerapah, dan Pohon Kelapa; Menjala Ikan, Gambar Berantai, Pesan Berantai, Cerita Berantai, Caca bucaca, Wajah Siapa?, Pindahkan Aku, Si Buta Menggambar, Gayaku dan Gayamu, Oke; Aku Berguna Untuk......, Dengar dan Lakukan, Tebak Benda, Tebak Gerak, Menggiring Balon, Mencari Teman, Mencari Potongan yang Sesuai, Awal Sebuah Kata, Bantu Aku Menemukan, Memilih, Mewarnai, Menggunting dan Menempel; Estafet Bendera, Merangkak, Melompat, Berlari), Ambilkan Sepatuku, Melompat Bersama, Menyeberangi Jembatan, Puzzle Kelompok, Menyusun Kepingan Geometri, Membangun Istana, Membangun Menara, Perahu Penyelamatan, Kapal Karam, Mainkan Perkusimu, Pijat, Palu, Babat ; dan Hadap, Balik, Bubar.

Permainan yang dirancang dalam panduan yaitu sebanyak 60 permainan diarahkan untuk mengembangkan kemampuan sosial emosional seperti menunjukkan sikap mandiri, mengendalikan perasaan, menunjukkan rasa percaya diri, mengekspresikan emosi sesuai dengan keadaan, memiliki sikap gigih (tidak mudah menyerah), bangga terhadap hasil karya sendiri, mau berbagi, menolong, dan membantu teman; menunjukkan antusiasme dalam melakukan permainan kompetitif secara positif; menaati aturan yang berlaku dalam suatu permainan; menjaga diri sendiri dari lingkungannya; dan menghargai orang lain. Hal ini sesuai dengan arah pengembangan sosial emosional anak yang ada dalam kurikulum pembelajaran TK dalam Permendiknas. Pengembangan sosial diharapkan dapat mengarahkan anak dari sifat egosentris ke arah sosiosentris, memperluas pertemanan anak, dan membantu anak belajar menyesuaikan diri agar dapat diterima secara sosial.

\section{Pembahasan}

Metode pembelajaran diperlukan agar materi pembelajaran dapat disampaikan dengan menarik, sehingga meningkatkan minat belajar peserta didik. Selama ini guru telah menerapkan permainan sebagai salah satu metode pembelajaran di TK, namun masih jarang dilakukan dan belum banyak pengembangan permainannya. Pada umumnya permainan dilakukan untuk mengembangkan kemampuan fisik motorik kasar anak, sedangkan permainan untuk mengembangkan aspek lain masih jarang dilakukan. Hal ini disebabkan dengan terbatasnya buku panduan permainan untuk anak dan masih sedikitnya pelatihan yang dapat mendorong guru untuk mengembangkan permainan dalam pembelajaran di TK.

Panduan permainan dalam penelitian ini berisi 60 permainan anak yang dilengkapi dengan nama permainan, tujuan permainan, alat dan bahan yang digunakan, langkah-langkah, refleksi permainan, serta variasi permainan. Panduan permainan ini dinyatakan layak untuk diujicobakan di lapangan. Hal ini dapat dilihat dari hasil penilaian validator yang secara keseluruhan, apabila data kuantitatif dikonversikan ke data kualitatif diperoleh hasil untuk uji materi 84,37\% (Baik) dan hasil untuk uji media 87,5\% (Sangat Baik).

Panduan ini juga disertai dengan ilustrasi gambar agar memberikan 
kemudahan pengguna panduan dalam memahami penerapan atau praktek permainan. Hal ini sesuai dengan pendapat Angkowo dan Kosasih (Musfiqon, 2012: 32), yang mengungkapkan bahwa salah satu fungsi media pembelajaran adalah sebagai alat bantu pembelajaran yang ikut mempengaruhi situasi, kondisi dan lingkungan belajar dalam rangka mencapai tujuan pembelajaran yang telah diciptakan dan didesain oleh guru. Desain media yang disertai gambar dapat memberikan kemudahan dalam memahami praktek permainan.

Permainan-permainan dapat dilakukan di dalam kelas (indoor) maupun di luar kelas (outdoor), dengan alat dan bahan sederhana yang dapat divariasi dengan media yang ada di TK agar tidak merepotkan. Hal ini sesuai dengan pendapat BEF Montolalu (2009) yang menjelaskan bahwa apabila ditinjau dari pelaksanaannya, kegiatan bermain terdiri dari bermain bebas dan bermain terpimpin.

Melalui permainan, pengembangan aspek sosial emosional seperti: mampu menunjukkan sikap mandiri, mengendalikan perasaan, menunjukkan rasa percaya diri, menunjukkan sikap toleran, mengekspresikan emosi sesuai dengan keadaan, menunjukkan rasa empati mampu menghargai perbedaan orang lain, memiliki sikap gigih (tidak mudah menyerah), bangga terhadap hasil karya sendiri serta mau berbagi, menolong, mau membantu teman; menunjukkan antusiasme dalam melakukan permainan kompetitif secara positif; menaati aturan yang berlaku dalam suatu permainan; menjaga diri sendiri dari lingkungannya; dan menghargai orang lain diharapkan dapat berkembang sesuai harapan, bahkan bekembang sangat baik.

\section{KESIMPULAN}

Kegiatan pengembangan yang dilakukan meliputi pengembangan prototipe panduan permainan untuk mengoptimalkan perkembangan sosial emosional anak. Prototipe panduan permainan terdiri dari 60 permainan yang masing-masing disertai dengan nama permainan, tujuan permainan, media yang digunakan, langkah-langkah permainan, refleksi, dan variasi permainan serta disertai dengan ilustrasi gambar permainan. Prototipe panduan kemudian divalidasi oleh ahli media dan ahli materi yang hasilnya menyatakan bahwa prototipe panduan layak untuk diujicobakan. Secara keseluruhan, apabila data kuantitatif dikonversikan ke data kualitatif diperoleh hasil untuk uji materi $84,37 \%$ (Baik) dan hasil untuk uji media $87,5 \%$ (sangat baik).

\section{DAFTAR PUSTAKA}
Agoes Dariyo. (2007). Psikologi Perkembangan Anak Tiga Tahun Pertama. Bandung: PT Refika Aditama.

Anggani Sudono. (2000). Sumber Belajar dan Permainan PAUD. Jakarta: Grasindo.

BEF Montolulu. (2009). Bermain dan Permainan Anak. Jakarta: Universitas Terbuka.

Borg, W.R \& Gall, M.D. (1983). Educational Research an Introduction. Fourth Edition. New York: Longman Inc.

Diana Mutiah. (2010). Psikologi Bermain Anak Usia Dini. Jakarta: KencanaPrenada Media Group.

Hurlock, Elizabeth $\quad$ B.
Perkembangan Anak.
Erlangga.

Mayke S Tedjasputra. (1995). Bermain, Mainan dan Permainan. Jakarta: Depdikbud. Direktorat Jenderal Pendidikan Tinggi.

Mursalin. (2011). Tahap Bermain Pada Anak. [Online]. Tersedia: 
http://mursalinnersboyz.blogspot.com/2011/02/tah ap-perkembangan-bermain-padaanak.html. [21 Oktober 2013].

Pendidikan Anak Usia Dini. http://id.wikipedia.org/wiki/Pendidi kan_anak_usia_dini_diakses tanggal 10 Maret 2015.

Santrock, John W. (2009). Perkembangan Anak. Jakarta: Erlangga.

Suharsimi Arikunto. (2006). Prosedur Penelitian. Jakarta: PT Rineka Cipta.

Soe, Dockett dan Fleed, Marilyn. (2000). Play and Pedagogy in Early Childhood. Australia: Harcout.

Syamsu Yusuf LN. (2004). Psikologi Perkembangan Anak dan Remaja: Bandung PT Remaja.

Yudrik Jahja. (2011). Psikologi Perkembangan. Jakarta: KencanaPrenada Media Group.

Yuliani Nurani Sujiono. (2010). Bermain Kreatif Berbasis Kecerdasan Jamak. Jakarta: PT Indeks. 